\title{
The Entreprenuerial Marketing: Concept, Nature And Orientations.
}

\author{
Prof. Pushpa Hongal, Dr. N. Ramanjaneyalu, Dr. Gururaj Phatak \\ Assistant Professor and Research Scholar \\ Kousali Institute of Management Studies Karnatak University Dharwad \\ Professor and Research Guide \\ Kousali Institute of Management Studies Karnatak University Dharwad \\ Assistant Professor \\ Department of Studies in Management GM Institute of Technology Davangere
}

\begin{abstract}
Entrepreneurial Marketing is the old and untouched, unfocussed Entrepreneurship and Marketing topic. Its research is has started around 30 years old. The purpose of this paper is to discuss the Evolution and the Nature of Entrepreneurial Marketing, Historical perspective of the Evolution of EM and Six core dimensions of entrepreneurial marketing are identified. The Research aims to focus on the Marketing Orientation as well as Entrepreneurial Orientations in Venture Creation and Management. A comprehensive assessment of the most representative publications from worldwide marketing and entrepreneurial journals was employed in this conceptual study. This study provides a brief overview of the evolution of EM as well as an examination of the most frequent definitions. Insights are drawn from a variety of sources, including corporate entrepreneurship, innovation and new product creation, creative leadership, and change management research. Entrepreneurial marketing's intellectual substance and validity are assessed. Priorities for future study are offered, as well as consequences for theory development, training, and management practise.
\end{abstract}

Keywords: Entrepreneurship, Marketing, Entrepreneurial Marketing, Entrepreneurial Orientation, Marketing Orientation.

\section{Introduction to Entrepreneurial Marketing:}

Companies find themselves operating in a new competitive landscape. Increased risk, lower capacity to foresee, fluid company and industry borders, a managerial mindset that must relearn classic management concepts, and new structural forms that not only allow for change but also help produce it are all characteristics of today's business climate. This new landscape has been characterized in terms of four overriding forces: change, complexity, chaos, and contradiction (Bettis and Hitt, 1995; Hitt and Reed, 2000).

What are implications of the new competitive landscape marketing? Do the roles and responsibilities of the marketing function within the firm change under such circumstances? On the one hand, it might be argued that the fundamental precepts of marketing remain unchanged but more attention must be given in the contemporary environment to customization and one-to-one approaches, relationships, networking, strategic alliances, globalization, and technology (Day and Montgomery, 1999). On the other hand, it may be that marketing itself should be reconceptualized. Srivastava, Shervani and Fahey (1998, p. 168) note: "Extending existing theoretical frameworks may no longer be sufficient to reflect marketplace shifts and guide marketing practice in the fundamentally new competitive context and conditions that will characterize the new millennium." It is this latter alternative, the idea that there is a need to fundamentally rethink the marketing function itself that is the focus of this paper. 
Recent years witnessed the application of number of adjectives to describe new approaches to the marketing function, including "guerrilla marketing", "proactive marketing", "subversive marketing", "expeditionary marketing", and "disruptive marketing". At the same time, marketing courses and curricula are increasingly embracing modules or courses on creativity and innovation. Interest in the marketing/entrepreneurship interface has never been higher.

\section{History and Evolution of Entrepreneurial Marketing:}

EM was first presented in a conference sponsored by the International Council for Small Business and the American Marketing Association, two of the major professional and academic groups in these fields, at the University of Illinois in Chicago in 1982. The most important research subjects were formed at this period, even though marketing academics' interest in this area was still restricted at the time. Since 1986, an annual conference dedicated to the subject has been held ME And is recognised by the American Marketing Association (AMA). EM subjects proliferated across Europe, and the Academy of Marketing hosted the first conference on the subject in 1995. The researchers' enthusiasm grew, and they formed a Marketing and Entrepreneurship Task Force, which ultimately became a permanent Special Interest Group. As a specific platform for EM researchers, the Journal of Research in Marketing and Entrepreneurship was launched in 1999. The results of the research on this topic have been published Special issues of marketing journals (European Journal of Marketing, Marketing Education Review, Management Decision, Journal of Marketing: Theory and Practice) and entrepreneurship journals (European Journal of Marketing, Marketing Education Review, Management Decision, Journal of Marketing: Theory and Practice) (European Journal of Marketing, Marketing Education Review, Management Decision, Journal of Marketing: Theory and Practice) (Journal of Small Business Management, International Journal of Entrepreneurship and Innovation Management).

The issue was taken outside of the Anglo-American context when the first symposium on marketing, entrepreneurship, and innovation was held in Karlsruhe, Germany, in 2003. The Special Interest Group later included Australia, New Zealand, and Asia academics. The MEI launched the International Journal of Entrepreneurship and Innovation Management in 2005 to bridge the gap between technology and marketing challenges. In 2008, special editions of the Journal of Small Business Management and the International Journal of Entrepreneurship and Innovation Management demonstrated that EM has made its way into the mainstream of entrepreneurship research. In 2010, during the "Charleston Summit" in Charleston, South Carolina, it was clear that marketing had become a secondary component of ME, which was dominated by entrepreneurship, and that attempts to reintegrate it were needed.

In the following table (Table 1) the most important milestones in the evolution of EM are presented.

\begin{tabular}{|c|l|}
\hline Year & \multicolumn{1}{|c|}{ Milestones } \\
\hline 1982 & First marketing and entrepreneurship research conference (G. Hills) \\
\hline 1985 & $\begin{array}{l}\text { First empirical study of the MEI in frontiers of entrepreneurship research } \\
\text { (G. Hills) }\end{array}$ \\
\hline 1986 & $\begin{array}{l}\text { First research symposium in marketing and entrepreneurship University of } \\
\text { Illinois at Chicago/ AMA (G. Hills) }\end{array}$ \\
\hline $1989-1991$ & $\begin{array}{l}\text { AMA Task Force (1989) and later, Special InterestmGroup is established } \\
\text { for the MEI. First Tracks are created in the AMA summer (1990) and } \\
\text { winter (1991) conferences for EM. }\end{array}$ \\
\hline 1995 & $\begin{array}{l}\text { Carson, Cromie, McGowan, and Hill publish first textbook Marketing and } \\
\text { Entrepreneurship in SMEs: An Innovative Approach }\end{array}$ \\
\hline 2005 & $\begin{array}{l}\text { Journal of Research in Marketing and Entrepreneurship created (J. Day, P. } \\
\text { Reynolds, D. Carson, G. Hills) }\end{array}$ \\
\hline 2007 & $\begin{array}{l}\text { International Journal of Technology Marketing created } \\
\text { Marketing Publishing published Marketing that Works: How Entrepreneurial } \\
\text { Lodish, Morgan, and Archambeau }\end{array}$ \\
\hline 2010 & $\begin{array}{l}\text { Special issue of Int. J. Entrepreneurship and Innovation Management on the } \\
\text { EM }\end{array}$ \\
\hline
\end{tabular}


(Source: Adapted from Hills G.E, Hultman C.M, Miles M.P (2008), "The Evolution and Development of Entrepreneurial Marketing”, Journal of Small Business Management, 46(1), pp. 103-104.)

\section{Contemporary Definitions of Marketing and Entrepreneurship:}

To understand entrepreneurial marketing, we need first to establish the meaning of the terms "marketing" and "entrepreneurship". Prevalent conceptualizations marketing center on set of activities that facilitate exchange relationships. Consider a commonly accepted definition promulgated by the American Marketing Association: "Marketing is the process of creating exchanges that meet individual and corporate goals by planning and executing the creation, pricing, promotion, and distribution of ideas, commodities, and services" (See Bennet, 1988).

In a related vein, Pride and Ferrell (2000, p. 14) define marketing management as "the planning, arranging, implementing, and supervising of marketing efforts in order to allow successful and efficient exchanges." Zikmund and D'amico (2001) indicate that any definition of marketing must include five components: two or more parties, something that is given up by each party, something that is received by each party, some level of communication between the parties, and some mechanism to perform the exchange.

The marketing activities alluded to in most definitions are generally organized into four interrelated categories: product, price, promotion, and distribution. Virtually any controllable mechanism for facilitating transactions will fall into one of these categories. Further, if it is assumed that exchange occurs when a buyer perceives that value is being created by a seller, then all of the available mechanisms for creating customer value can be classified into these categories.

When combined, the myriad decisions that comprise these four categories of activities are referred to as the "marketing mix". The goal of strategic marketing is to combine the parts of the marketing mix in a way that reflects the demands of major target consumer populations while also allowing the company to stand out from rivals on a long-term basis. Furthermore, as goods progress through their life cycles, the marketing mix ingredients are adjusted over time to reflect changing market dynamics.

Marketing is predicated on an underlying philosophy commonly referred to as the "marketing concept". It is a customer-oriented philosophy built around three elements:

- All activities of the firm should be based on customer needs,

- A customer focus should be integrated throughout the firm,

- Customer satisfaction is viewed as the means to long-term profitability.

This philosophy guides the firm's marketing strategy, including its selection of target audiences, design of the marketing mix, allocation of marketing resources, and activities for monitoring marketing performance.

Now let's talk about entrepreneurship. Entrepreneurship may be defined as a process that takes place in businesses of all sizes and sorts (Bygrave, 1989; Cornwall and Perlman, 1990; Morris and Kuratko, 2001; Pinchot, 2000). "The process of producing value by bringing together a unique bundle of resources to seize an opportunity," according to Stevenson, Roberts, and Grousbeck (1989).

The tasks required to find an opportunity, design a company model, assess the required resources, acquire those resources, then manage and harvest the endeavour are all part of the process. To carry out these activities, you'll need two things: an entrepreneurial event and an entrepreneurial agent. The event entails the creation and execution of a new concept (i.e., a new product, service, or process), and the agent is the individual or group in charge of making it happen.

The concept of entrepreneurship has three underlying dimensions: innovativeness, risk-taking, and proactiveness (Covin and Slevin, 1994; Ginsberg, 1985; Miller and Friesen, 1983; Morris and Paul, 1987). The pursuit of creative, unconventional, or original solutions to issues and demands is referred to as innovativeness. It encompasses the creation of new goods and services, as well as new methods and technology for carrying out organisational tasks. (e.g., production, packaging, delivery, sales, promotion, and administration). Risk-taking involves willingness of managers to commit significant resources opportunities that have a reasonable chance of costly failure. The hazards are reasonable, measured, and managed, rather than excessive and uncontrollable. 
Implementation is concerned with proactiveness, or making things happen by any means required. It usually necessitates deviating from traditional methods of finishing a task and necessitates a hands-on management approach. It typically entails a great deal of tenacity, adaptation, and a willingness to accept some blame for failure.

The term "entrepreneurial marketing" has been offered as an integrative paradigm for conceptualising marketing in an era of increasing information intensity and constant change in the environment in which businesses operate. It can be defined as "a proactive, innovative, risk-taking approach to the identification and exploitation of opportunities for attracting and retaining profitable customers". Defined in this manner, entrepreneurial marketing (EM) represents an opportunistic perspective, with the marketer not simply responsible for communication activities, but also for continually discovering new sources of value for customers and new markets for the firm. The emotional side of effective market positioning for firms like Harley Davidson, Southwest Airlines, and Snap-On Tools is the value provided via fresh techniques. Southwest is a good example. the parts of the marketing mix that defy conventional wisdom in the business Importantly, EM represents different approach envisioning the business itself, its relationship with the marketplace, and the role the marketing function within the firm. As a result, the company is considered as a "innovation factory," with all departments and activities described in terms of an internal value chain and a continuous duty for discovering new sources of consumer value. In terms of the marketplace, the company prefers to lead customers rather than respond to or follow them, and it focuses on creating new markets rather than better servicing existing ones. The majority of marketing's work inside a company is built around six fundamental dimensions:

1. Customer Intensity.

2. Sustainable Innovation.

3. Strategic Flexibility.

4. Calculated Risk taking.

5. Environmental Pro-activeness

6. Resource Leveraging

Customer Intensity: Largely ignored in marketing theory and empirical research is emotional aspect the successful market positioning such companies as Harley Davidson, Southwest Airlines and Snap-On Tools. Southwest is a case in point. The organisation uses the term "spirituality" to indicate fundamental convictions about the employee's position, the nature the customer experience, and how the two are related. As Hamel and Prahalad (1994, p. 128) note, "Getting to the future first is more a function of resourcefulness than resource. "Resourcefulness comes from a genuinely felt sense of purpose, a broadly shared aspiration, and a truly enticing perspective of tomorrow's possibility, not from an elegantly planned strategic architecture."

We suggest the phrase "customer intensity" to describe a sense of conviction, emotion, fervour, excitement, and belief in where marketing is trying to lead the company and how it intends to get there. Entrepreneurial marketers contribute more than technical expertise to the marketing assignment; they emphasise the importance of all employees identifying at a basic level with the firm's goods and brands, what they stand for, and, ultimately, with the firm's customer value proposition.

Sustainable Innovation: Sustained innovation, according to Runser-Spanjol (2001), is the ability to maintain a flow of internally and externally inspired new ideas that may be translated into new goods, services, processes, technological applications, and/or markets at an organisational level. It is an organisational quality or trait that comes from a complicated collection of interrelationships.

A range, or continuum, of innovation possibilities exists. In terms of products and services, marketers can champion or play an active role in efforts involving innovations that are new- to-the-world, new-to-the-country or the market, new lines for the company, additions to lines, product/service revisions, new applications of existing items, and repositioning of existing items. In the area of process innovation, a wide range of possibilities exist, from new administrative systems and service delivery systems to alternative distribution approaches and new organization forms or structures.

Marketing plays an important role in long-term innovation, with responsibilities ranging from opportunity discovery and concept formulation to technical assistance and creative resource augmentation. Process innovation becomes a cornerstone of marketing operations. As a result, CEOs are constantly arguing for new 
approaches to segmentation, pricing, brand utilisation, packaging, CRM, customer credit, logistics, customer communication, and service levels, among other things.

Strategic Flexibility: Firms must achieve a balance between market-leading efforts and swift, innovative adaptability to changing market conditions in their innovation operations. Strategic flexibility refers to a company's readiness to rethink and alter its strategies, action plans, and resource allocations, as well as its structure, culture, and management processes, on a regular basis. How quickly and adroitly can marketers adapt to changes in the competitive set or in competitor strategies, to a shift in the power or change in the structure within the value chain, or to changes in the availability or cost of components and raw materials? These modifications take into account the fact that management understands where the company wants and how it wants to be positioned, but there are several paths to get there. Flexibility necessitates a thorough understanding of the company's resources, skills, and competencies.

Opportunities are flexible and move in new directions by definition. Marketing must direct the company's efforts in predicting how the variables that comprise an opportunity will change over time and how the company may adapt in creative ways. The marketing function helps the company's strategic flexibility and, as a result, its capacity to adapt. Flexible human capital and resource leveraging; strategic partnerships and alliances combined with a global market presence; limited levels of commitment to specific products, markets, and technologies; and effective incorporation of new emerging technologies (i.e., technologies that enable firm quickly recognise changing market needs or conditions, customise products, and serve different markets in different ways) can all help to increase flexibility (See Hitt and Reed, 2000).

Calculated Risk-taking: Risk-taking involves willingness pursue opportunities that have a reasonable chance of producing losses or significant performance discrepancies (See also Venkatraman,1989, who uses the term "riskiness"). Our emphasis is not on high or completely uncontrollable risks but instead on risks that are moderate and calculated. Entrepreneurial marketing does not imply rash decisions, but rather a fair understanding of the risks (financial, technological, market-related, and human) and an attempt to manage such risks. These risks are mirrored in an organization's numerous resource allocation decisions, as well as the goods, services, and markets that are prioritised. Every company has a risk profile, even if it isn't stated openly in most cases. Over time, this risk profile changes.

Marketing has responsibility for developing a keen on this risk profile and then for managing risks in a way that reflects the profile. Intelligence collecting initiatives, test markets, working with lead customers, phased product releases, outsourcing of different operations connected to a new product or service, borrowing or sharing resources, and collaborations with suppliers, distributors, and rivals are all used to mitigate risk. In their discussion of "expeditionary marketing", Hamel and Prahalad (1992) use a baseball analogy in suggesting that successful hits (new products, services, processes) are a function of the company's hit rate (or batting average) times the number of times the firm comes to bat. Arguing that firms are preoccupied with their batting average, these authors highlight the need to place far more focus on frequency of times at bat.

The conclusion is that by innovating more, with lots of lower risk market incursions that involve exploring multiple market niches, a firm actually reduces its risk profile to a more manageable level. A systematic approach to organisational learning is a significant component of this strategy. Marketing well-designed marketing intelligence systems may help organisations swiftly understand what works and what doesn't in a specific entrepreneurial venture and then apply those lessons to subsequent experiences.

A different perspective is provided by Dickson and Giglierano (1986), who have provided one of the only articles to appear in the Journal of Marketing that explicitly address entrepreneurial risk-taking. The authors propose that marketers must consider two sides of the risk equation. The typical concern is with pursuing an entrepreneurial idea that does not work out, or "sinking the boat" risk. It is reflected in such factors as a poorly conceptualized product, bad timing, an already well-satisfied market, inadequate distribution, and inappropriate price levels. The other side of the risk equation is concerned with "missing the boat", or the risk pursuing a course of action that would have proven profitable. It occurs when the firm delays action on a concept for too long and is preempted by competitors or changing market requirements. The firm misses the window of opportunity by being too cautious or conservative and often seeks more security in the form of additional market research, financial data, or inputs from consultants.

Environmental Pro-activeness: The entrepreneurial marketer does not accept the external environment as a given or a set of conditions to which the company can simply respond or change. The environment is characterised as a vista of opportunity. While admitting areas where the company is more reliant on third 
parties or sensitive to external events, marketing activities are proactive in nature and aimed at promoting environmental change. More precisely, the marketer tries to reshape components of the external environment in order to minimise environmental uncertainty, lower the business's reliance and vulnerability, and/or change the task environment in which the firm functions. In other words, the marketer is increasing the firm's ability to determine its own destiny.

Zeithaml and Zeithaml (1984) developed a taxonomy of environmental management strategies that included three broad types (independent, cooperative, and strategic manoeuvring) and 16 specific strategies. The majority of them plainly come under the purview of marketing, while some are aided in their execution by marketing efforts. Furthermore, certain environmental management techniques may be related to the firm's existing competitive position as well as product life cycle stages.

Flexibility demands keen insights into organization's resources, capabilities, competencies. Michael Dell, with Dell Computer, provides an illustration of environmental proactiveness. Dell effectively redefined the competitive rules of the computer industry through his Dell Direct Method, which permits high volumes of customized computers to be sold directly to customers at competitive prices. His volumes made him less vulnerable to the pressures of various suppliers, while his distribution approach removed the power of retailers over company operations. Moreover, by overturning assumptions regarding price/performance trade-offs, Dell established a sustainable and highly profitable strategic position. Another example can be found in the Grateful Dead rock band (See Hill and Rifkin, 1999). By establishing strong visceral ties with their customer base, inverting the conventional business model in terms of the relationship between album sales and concert tours, and employing a host of innovative tactics in merchandising, relationship management, and concert operations, the band created entry barriers and a level of differentiation that discouraged direct competitors and gave it significant leverage with organizations comprising the value chain in the music industry.

Resource Leveraging: At its most basic level, leveraging refers to doing more with less. Consider the base word "lever". Acting as a lever, a metal rod enables an individual to dislodge an object that could not otherwise be moved. Entrepreneurial marketers, in a similar vein, are master resource leveragers. Ambition always outpaces resources in their firms. The inference is that entrepreneurial marketers aren't limited by the resources they now possess or have available to them. They can make use of resources in a variety of ways. Stated differently, the concept of resource leveraging has a number of aspects:

- Stretching resources much farther than others have done the past;

- Getting uses out resources that others are unable to realize;

- Using other people's (or firm's) resources accomplish one's own purpose;

- Complementing one resource with another create higher combined value;

- Using certain resources obtain other resources.

Leveraging not something one simply decides to do. It creative rather than mechanical process. Marketers develop a capacity for resource leveraging. Some are more creative, others less so. It takes knowledge, experience, and expertise to discover a resource that isn't being used to its full potential, see how the help may be used unconventionally, and persuade people in charge of the resource to allow the marketer to use it. The capacity to influence team members to work beyond hours, persuade departments to conduct things they would not typically perform, or bring together unique combinations of synergistic resources when combined are all examples of this.

The capacity to leverage other people's resources to attain the marketer's goal is possibly the most important form of leveraging strategy stated. Bartering, borrowing, renting, leasing, sharing, recycling, contracting, and outsourcing are all examples of how this is done. These efforts can be aimed towards different departments and divisions inside the company, as well as external parties such as suppliers, distributors, customers, and other businesses. Informal initiatives, such as the trading of favours and the utilisation of networks, are widely used, as are official initiatives, such as strategic alliances and joint ventures. Discussions of resource productivity can also be misconstrued, at least in some companies. The leveraging philosophy is not about cutting resources or squeezing them as much as possible in an attempt to increase productivity. Managers seeking to create a "lean and mean" enterprise often find the end result 
is more "mean" than "lean". The long-term outcome is frequently less productivity and more inefficiency. Rather, leveraging is about finding and using resources more intelligently, more creatively, and in a more focused manner.

It's worth noting that the six components that make up entrepreneurial marketing aren't mutually exclusive. As a consequence, risks may be reduced by leveraging resources through outsourcing, which leads to increased strategic flexibility. Resource leveraging form of strategic partnership can help with innovation, but it can also increase the firm's reliance on a third party. Furthermore, for entrepreneurial marketing to occur, not all of the characteristics must be active at the same time. The marketer could engage in significant innovation that redefines environmental conditions, involves high levels of customer intensity, and involves numerous risks, some of which the marketer can mitigate, but resources aren't being leveraged, and the required approach may result in little strategic flexibility.

To put it another way, EM is a question of degree, and different combinations of the underlying factors will result in more or less entrepreneurial marketing. When taken together, these six elements provide a style of marketing that is considerably different from traditional marketing. EM is primarily a method of thinking and action that is driven by and seeks for opportunities.

Moreover, entrepreneurial marketing differs in that returns the discipline its roots as creative pursuit and art. Thus, the traits of creativity, vision, intelligence, and originality associated with entrepreneurial activity are applied to the complete spectrum of marketing operations, from market research and segmentation to marketing mix management, in this paradigm of marketing.

This isn't to say that science, theory, methodical methods, and sophisticated discoveries aren't important components of EM. If this school of marketing have a long-term influence, these factors must play a key role. The problem is that much current theory, as well as many marketing frameworks and tools, do not accommodate or aid our understanding of entrepreneurial action.

\section{Marketing and Entrepreneurial Orientation:}

A new stream research describes marketing orientation firms as "entrepreneurial marketing". This means style of marketing behaviour that driven and shaped by owner or manager's personality.

Kohli and Jawroski (1990) suggested that 'entrepreneurial marketing' is merely the implementation of the marketing concept reflected in the activities and behaviors of an organization as opposed to some innovative concept. These include Market Focus, Customer Satisfaction, Coordinated Marketing and Focus on Profitability.

More predominant is the management style approach that concludes the marketing orientation of the firm is depend on the personality and characteristics of the owner manager or lead entrepreneur or chief decision maker, in the main management function is aspect to the marketing orientation emphasis importance of marketing for firms growth, survival and strategic development.

Entrepreneurial orientation is aggressiveness, innovative logistics, adaptiveness, a high rate of new product or service introduction and on emphasis on product or service innovations. Entrepreneurial orientation refers to propensity of company's top management to take calculated risk, to be innovative and to demonstrate proactiveness. Such reference to risk taking is strongly character of much entrepreneurship research.

\section{Scope for Further Research:}

The most often employed methodologies during the early period were qualitative. Entrepreneurs, their habits, and how they make decisions piqued academics' interest. The researchers needed an insider view to have a thorough grasp of the phenomena, approach it as much as possible, and monitor it over time. This was impossible to do using traditional quantitative approaches. Focus group discussions, in-depth interviews, observations, ethnographies, and conversational analysis were needed instead of quantitative methods.

In the evolution of entrepreneurial marketing, there is still a lot of work to be done. Richer insights into the six dimensions of EM, for example, are required, as is study into the interrelationships between these dimensions. It's critical to understand possible conflicts and their ramifications, such as how particular resource leveraging strategies make the company more subject to external influences. Obstacles to 
entrepreneurial marketing in businesses should be researched more and strategies for overcoming them. A priority should be the obstacles originating from within marketing departments or among those having marketing responsibilities. Entrepreneurial Marketing research main problem is that is individualistic and fragmented, therefore progress is slow. A synergistic strategy is required, comparable to how academics in other social sciences collaborate on a given study field while independently examining a distinct research challenge.

\section{Conclusions:}

As previously said, EM has failed to create its paradigm in the last thirty years. The fundamental reason is that no one had a shared grasp of the term. As a result, in 2010, a representative group of experts assembled in Charleston, South Carolina, USA, for the "Charleston Summit" to examine the past and future of EM. The summit's primary purpose was to develop a framework, model, or paradigm to guide future research at the intersection of marketing and entrepreneurship.

It was determined that four distinct techniques emerged throughout time. The first method, traditionally the most popular, concentrated on the parallels between marketing and entrepreneurship. The second method is called "entrepreneurship in marketing," It is based on a marketing framework that introduces aspects of entrepreneurship or a specific setting.

Progress in these areas will help to solidify entrepreneurial marketing's stature as more than a passing fad. In the final analysis, entrepreneurial marketing holds much potential for not only for reversing the potential marginalization of marketing but also for making it a driving force within firms in the achievement of competitive advantage on a sustainable basis.

We must recognise that several meanings will exist, without diminishing the necessity of adopting a widely agreed definition. The creation of particular concepts and practical instruments to steer entrepreneurial enterprises through difficult times is increasingly crucial at this time. And only a concerted, disciplined effort can attain these goals.

\section{References:}

1. Gerald E. Hills, Claes M. Hultman, and Morgan P. Miles. 2008. The Evolution and Development of Entrepreneurial Marketing. Journal of Small Business Management

2. M H Bala Subrahmanya.2011.Technological Innovations and Firm Performance of Manufacturing SMEs: Determinants and Outcomes by ASCI Journal of Management.

3. Daniela IONIŢĂ: Entrepreneurial Marketing. 2012 Vol. 7. A New Approach for Challenging Times by Management \& Marketing Challenges for the Knowledge Society.

4. Gerald Hills and Raymond W. LaForge.1992. Research Marketing Interface Advance Entrepreneurship Theory by Entrepreneurship and Practices Bayer's University.

5. Suliyanto.2011.Vol 2. "Effect of Entrepreneurship Orientation and Marketing-Based Reward System towards Marketing Performance". International Journal of Business and Social Sciences.

6. Keith Perks, Markus Steinhauser, Paurav Shukla. 2009. "Factors Affecting Entrepreneurs' Decision to Enter New Markets: Propositions and Theorized Influences" by ANZMAC.

7. Hulya Kurugan, Demet Bugiran, Emir Ozeren, Begum Maral. 2011. Vol.26. Entrepreneurial Marketing-The Interface between Marketing and Entrepreneurship. A Qualitative Research on Boutique Hotels, European Journal of Social Sciences ISSN 1450-2267

8. Aodheen O’Donnell. 2004. Vol 7. Nature of Networking in Small Firms. Qualitative Market Research an International Journal.

9. Alberto Marcati, Gianluigi Guido, and Alessandro M. Peluso: What is Marketing for Entreprenuers? The Need to Market and Marketing Approach.

10. Jaworski, B.J. and Kohli, A.K. (1993), "Marketing Orientation: Antecedents and Consequences," Journal of Marketing, 57 (July), pp. 53-71. 